\title{
Economic fluctuations and monetary policy on the stock market during the COVID-19 pandemic in Indonesia
}

\author{
Suriani $^{1 *}$, Muhammad Nasir $^{1}$, and Ernawati ${ }^{1}$ \\ ${ }^{1}$ Faculty of Economics and Business, Universitas Syiah Kuala, Indonesia
}

\begin{abstract}
The purpose of this study is to examine the stock market's resiliency in the face of economic fluctuations and a crisis caused by the COVID-19 outbreak. using monthly data from 2011 to 2020 and an error correction model with the Composite Stock Price Index (conventional stock market system) and the Jakarta Islamic Index (Islamic stock market system) as dependent variables and policy interest rates, exchange rates, inflation, and crises as independent variables. In both stock market models, the regression results reveal that there is a short-term to long-term equilibrium relationship. Interest rates set by policymakers and crisis variables have a detrimental impact. In the long run, the exchange rate has a beneficial effect, and inflation has no influence on the two stock markets. In the short run, the findings in both markets are nearly identical, meaning that inflation and policy interest rates have little influence, whereas exchange rates have a negative impact. The crisis, on the other hand, had no impact on the JCI stock market. The crisis had a positive impact on the JII stock market, unlike the JII stock market. These findings are significant because they reveal a distinction that leads to a significant increase in the number of investors who believe it is safe to invest in the Islamic stock market in the short term, notwithstanding the crisis.
\end{abstract}

\section{Introduction}

Every developing country desires sustained economic growth conditions. However, in the event of an unavoidable recession caused by an economic crisis, optimal preparation and strategy are required to resolve the problem. A recession is an economic condition characterized by a decline and sluggishness in aggregate economic activity. It can be stated from the state of gross domestic product (GDP), which has decreased, or it can demonstrate that real economic growth has been negative for two consecutive quarters or for more than a year. Prolonged recessions can lead to economic depression and volatile price levels. According to reference [1], significant internal and external shocks can cause the occurrence of an economic recession, i.e. fluctuations in output (1).

Indonesia, as a developing country, was not invulnerable to the crises of 1997/1998 and 2008/2009. Currently, a recession could occur again if the data in Figure 1 show that Indonesia's economic growth was negative in the first two quarters of 2020 (BPS, 2020). At the end of 2018, economic growth was 5.18 percent in the fourth quarter. It continued to fall until the first quarter of 2020 (2.97 percent), then dropped precipitously to -5.32 percent in the second quarter of 2020 .

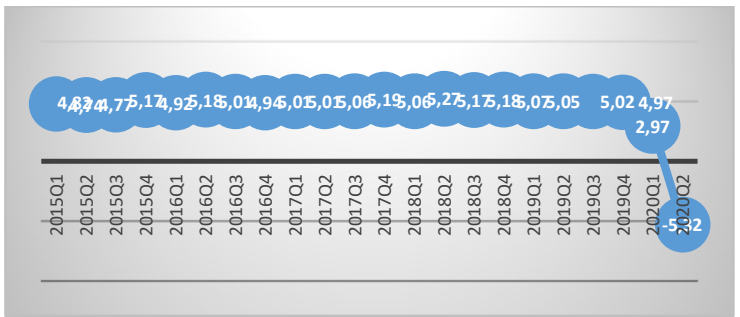

Fig. 1. Indonesia's Economic Growth (2015Q1-2020Q2).

It is known that the Covid-19 virus created a global pandemic in early 2020, which claimed many victims worldwide due to the virus's aggressive transmission. In terms of economics, the Covid-19 outbreak has had a significant impact on the fall in national income in a number of nations. Following the data presented in Figure 1, reference [2] claimed that the impact on the economy is predicted to be quite unfavorable, cutting Indonesia's estimated economic growth rate for 2020 from about 5 percent to between 4.2 and -3.5 percent. In the first two quarters of 2020, Indonesia's economic growth continued to deteriorate.

Indonesia has a dual financing system, namely conventional and sharia systems. The stock market is one of the essential sectoral of investment for Indonesia. The condition of the Covid-19 Pandemic affects alleconomy segmentation, especially for productivity to get national output. Covid-19 affect many people to produce goods and service. It disturbs the health caused the people not to work, income decreases, poverty increases, and the investment sector is not interest for investors.

\footnotetext{
*Corresponding author: suriani@unsyiah.ac.id
} 
Overcome to Covid-19 pandemic, Indonesia never stops trying to get the optimal strategies. In this case, the central bank of Indonesia (BI) used monetary instruments to control the unstable economic condition in Indonesia.

The goal of this study is to examine the state of economic fluctuations and monetary policy tools in sustaining financial system stability in the Indonesian stock market through interest rate policies. This study of the composite stock price index was conducted by the stock market, and the Jakarta Islamic Index reflects each system. During the Covid-19 pandemic, the study examined into the impact of inflation, currency rates, and policy interest rates on the composite stock price index (conventional stock market system) and the Jakarta Islamic Index (Islamic stock market system).

This research is necessary since the state of the Covid-19 pandemic has an impact on economic circumstances in all real sectors and has the potential to induce a recession. If the recession is not addressed quickly, it could lead to an economic depression. Both domestically and globally, bad things can have an impact on Indonesia's political and economic conditions. As a result, a solid strategy is required to provide the best answer for minimizing unfavorable economic conditions and avoiding a recession.

\section{Literature review}

\subsection{Macroeconomic economic fluctuation \\ determinants and}

The rise in national output over time is a useful indicator of a country's development process. However, current situations illustrate that global economic development in both emerging and developed countries can fluctuate. Internal and external shocks, according to reference [1], might induce output volatility. It is confirmed by the findings of reference [3], who discovered that financial shocks were the primary driver of cyclical fluctuations, particularly during the Great Recession.

During a recession, macroeconomic and industrial shocks can exacerbate the situation. Positive shocks have a short-term and unfavorable effect on output growth or price rebound in the long run, according to reference [4] research. The macroeconomic impact of cyclical fluctuations in the energy industry has a stronger price effect than an output effect and a greater impact on producers than on consumers.

According to reference [5], recession circumstances can also be caused by macroeconomic policy. Their findings are that I two countries are in a long-term recession, (ii) macroeconomic policies in the most prominent Arab countries do not generate dynamic gains from trade, (iii) inflationary pressures stimulate economic growth through domestic investment, (iv) financial integration and financial development suggest that structural reforms in the banking sector and financial markets are necessary, and (v) short-term stabilization is warranted.

However, it is clear that the relationship between recessionary conditions and macroeconomic sectors, such as the labor market in the trade sector, would change more than the relationship between recessionary conditions and non-trade labor sectors. Following to reference [6] findings, the recession and subsequent financial crisis have sparked a lot of interest in the causes of unemployment variations. The tradable sector provides employment over three times quite so many employees as the non-trade sector, and wages are approximately twice as volatile.

\subsection{Economic growth and pandemic recession}

The results of reference [7] research explained that the Covid-19 outbreak greatly affected the decline in national income in various countries. The International Monetary Fund (IMF) predicts that China's economy will slow down by -0.4 percent. Meanwhile, global growth will slow down by -0.1 percent. In addition, reference [8] estimates that world economic growth will be hit in the range of 3-6 percent, depending on the country. In another scenario, GDP could fall by more than 10 to 15 percent.

While reference [9] estimates that the real GDP contraction in the United States (US) year-on-year fell by almost 11 percent in the fourth quarter of 2020, with the 90 percent confidence interval extending to a contraction of nearly 20 percent. Prediction for Indonesia itself from research by reference [2] estimates that the economic impact is expected to be very bad, reducing Indonesia's projected economic growth rate for 2020 from around 5 percent to between 4.2 percent -3.5 percent.

The manufacturing sector has also been affected by the outbreak of the Covid-19 pandemic. First, supply disruptions will hamper production. Second, supply chain disruptions will make it difficult for countries less affected by Covid-19 to obtain the necessary imported industrial inputs from countries hit by the Covid-19 outbreak. Third, it will be demand disruptions due to a downturn in macroeconomic conditions or a recession. The public and other economic actors tend to "wait and see" and tend to postpone the purchase of consumer goods (especially durable consumption goods) and delay investment spending by companies [10]. This research focuses on the determinants of macroeconomic variables on recessionary conditions by paying attention to macro policy-namely monetary policy through interest rates and analyzing its effect on the conventional and sharia stock markets.

\section{Method}

This study employs a quantitative research method based on secondary data. The monthly data for this study's sample ranges from 2011 to 2020 . As a result, the total amount of data used is 120 . The information comes from the Indonesian central bank (BI) and the Financial Services Authority (OJK). Ordinary least squares regression with an error correction model (ECM) approach was used as the analytical method. The ECM model has the advantage of being able to predict both long-term and short-term effects. 
In this study, two equations of models are used: the first for the regression of the JCI stock market equation and the second for the regression of the JII stock market equation. All research variables must be stationary at first difference and cointegrated residuals in order for the ECM model to be chosen. The fact that the error correction term is negative is a distinguishing feature of ECM. To ensure that the regression results were valid and unbiased, the Classical assumption test was used.

This study focuses on economics, with the variables studied being economic growth and macroeconomic variables, as well as the study of Indonesian monetary policy. Using dummy variables, the analysis will be performed on economic fluctuations (recession) in Indonesia from 2011 to 2020 (monthly data) and crisis conditions during the pandemic.

\subsection{Model of analysis}

Multiple linear regression was used as an analytical method to establish the error correction model to be used. The model was chosen because it can predict the independent variables' short- and long-term effects on the two dependent variables over time. In this model, the stages of time series analysis are stationary data, cointegration, and the classical assumption.

To see the unit root test results, which are stationary in the same order, the Unit Roots test used in this study employs two methods, namely ADF (Augmented Dickey-Fuller) and PP (Phillips Perron) [11]:

$$
y_{t}=\rho y_{t-1}+\varepsilon_{t} \quad-1 \leq p \leq 1 \quad \ldots \ldots \ldots \ldots . . .
$$

In equation (3), the variable $t$ represents the stochastic error term as defined by the classical assumption, implying that the difference (variance) constant is zero, and y represents the time series. The data for unit roots is not stationary at level or 1(0), if the $p$-value is greater than one, the data should be tested at the first difference level, or 1(1) level. The first difference is that if the $y_{t}$ data is not stationary, it will regress the lag value of one period, $y_{t-1}$. The data is stationary if the first difference value of $\mathrm{p}$ smaller than 1 . The optimal lag test is then accomplished.

Cointegration is a useful notion for two or more nonstationary time series variables that will be cointegrated if the combination is also linear over time. It is possible, however, that each variable is not stationary. Starting with a long-term partnership, reference [12] illustrate the cointegration:

$$
y_{t}=a+b 1 x_{t}+\varepsilon_{t}
$$

Cointegration is included in the ECM model, according to Granger's Representation Theorem, which means that if $\mathrm{xt} \sim \mathrm{I}(1), \mathrm{yt} \sim \mathrm{I}(1), \mathrm{t} \sim \mathrm{I}(0)$, the $\mathrm{ECM}$ equation can be written as follows [13]:

$\Delta y_{t}=\alpha+\sum_{i=1}^{k} \beta i \Delta y_{t-1}+\sum_{i=0}^{k} \gamma \Delta x_{t-1}+\emptyset \varepsilon_{t-1}+\varphi t \ldots$.

Where $<0$ must have a negative, or a valid ECM must be negative and statistically significant. It means that the cointegration is convergent. The ECM model is created by incorporating the ECT value into the regression equation, as shown below:

$$
Y_{t}=\mu_{i}+\sum_{i=1}^{n} A_{i} \Delta Y_{t-1}+\sum_{i=1}^{n} \lambda \Theta_{t-1}+v_{t}
$$

The two equation models studied in this study can be written as follows:

Model 1:

$\Delta C S P I_{t}=\alpha_{1}+\gamma_{1} \Delta E R_{t}+\gamma_{2} \Delta I N F_{t}+\gamma_{3} \Delta B I r_{t}+\gamma_{4} \Delta D_{t}+$

$\gamma_{5}$ ECTCspi $_{t-1}+\varepsilon_{t}$

Model 2:

$\Delta J I I_{t}=\alpha_{1}+\gamma_{1} \Delta E R_{t}+\gamma_{2} \Delta I N F_{t}+\gamma_{3} \Delta B I r_{t}+\gamma_{4} \Delta D_{t}+$

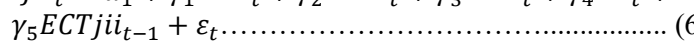

Where model 1 refers to a study of the sensitivity of changes in the conventional stock market as represented by the CSPI. Model 2 depicts the sensitivity of changes in the Islamic stock market via JII as a result of economic fluctuations and crises brought on by the Covid-19 outbreak in Indonesia. The validity of the regression results was then double-checked using the classical assumption test.

\section{Results and discussion}

Statistic descriptive of the data (Tabel 1) shows that the maximum value of exchange rate (ER) is IDR 16367, with an Inflation rate of $8.7 \%$, BIR 7.7, conventional stock of 6605, and JII 2376039. While the minimum value of the exchange rate (ER) is IDR 8532, with an Inflation rate of $1.32 \%$, BIR 3.75 , conventional stock 3409 , and JII 1016725. The fluctuations of the data shown from the changes of the maximum and minimum value of the data reach until $50 \%$ from 2011 to 2020 (monthly).

Table 1. Statistic descriptive of data.

\begin{tabular}{|l|c|c|c|c|c|}
\hline & ER & INF & BIR & CSPI & JII \\
\hline Mean & 12463.38 & 4.5 & 5.9 & 5073.7 & 1869297. \\
\hline Median & 13293.00 & 4.0 & 5.7 & 5077.5 & 1906429. \\
\hline Max & 16367.00 & 8.7 & 7.7 & 6605.6 & 2376039. \\
\hline Minimum & 8532.000 & 1.3 & 3.7 & 3409.1 & 1016725. \\
\hline Std. Dev. & 2186.104 & 1.8 & 1.2 & 834.30 & 309674.7 \\
\hline Obs & 120 & 120 & 120 & 120 & 120 \\
\hline
\end{tabular}

Whereas Model 1 describes the analysis conducted to determine the sensitivity of changes in the conventional stock market, Model 2 describes the sensitivity of changes in the Islamic stock market as a result of economic fluctuations and crises caused by the Covid-19 pandemic in Indonesia. This study relied on classic assumptions such as normality, multicollinearity, heteroscedasticity, and autocorrelation tests. Table 2 shows the results of the data stationarity test.

At the level of either the ADF-Fisher or PP-Fisher tests, all study variables are not stationary, as shown in Table 1. The ADF-Fisher and PP-Fisher tests, on the other hand, show that all are stationary at the first difference level. As a result, using these data as a guide, choose the correct ECM model, which is supported by 
the ECT value of Model 1 and Model 2, which both exhibit a substantial negative value on the stationary test at level or I(0). Because the residual variable (ECT) is cointegrated, it confirms that ECM regression may be done. Then, by analyzing the residuals and between the data's independent variables, utilize the classic assumption test to verify that the data is legitimate.

Table 2. Data stationarity test results.

\begin{tabular}{|c|c|c|c|c|}
\hline \multirow{2}{*}{ Variables } & \multicolumn{2}{|c|}{ ADF-Fisher } & \multicolumn{2}{|c|}{ PP-Fisher } \\
\hline & $\mathbf{I}(\mathbf{0})$ & I(1) & $\mathbf{I}(\mathbf{0})$ & I(1) \\
\hline CSPI & 0.1578 & $0.0000^{* * *}$ & 0.2760 & $0.0000 * * *$ \\
\hline JII & 0.1510 & $0.0000^{* * *}$ & 0.1471 & $0.0000^{* * *}$ \\
\hline INF & 0.1624 & $0.0000^{* * *}$ & 0.3513 & $0.0000^{* * *}$ \\
\hline ER & 0.6125 & $0.0000^{* * *}$ & 0.7501 & $0.0000^{* * *}$ \\
\hline BIR & 0.8573 & $0.0000^{* * * *}$ & 0.7651 & $0.0000^{* * *}$ \\
\hline ECT_model1 & $0.0033 * * *$ & - & $0.0025 * * *$ & - \\
\hline ECT_model2 & $0.0003 * * *$ & - & $0.0002 * * *$ & - \\
\hline
\end{tabular}

Table 3. Classic assumption test results.

\begin{tabular}{|c|c|c|c|}
\hline Tests & The Name of Tests & Model 1 & Model 2 \\
\hline Normality & Histogram & 0.1804 & 0.5011 \\
\hline Multicollinearity & VIF & $<10$ & $<10$ \\
\hline Autocorrelation & Correlation LM test & 0.1250 & 0.4583 \\
\hline Heteroscedasticity & Heteroscedasticity test & 0.0731 & 0.2862 \\
\hline
\end{tabular}

Description: (.) P-Value. Level of significance $\alpha$ di atas (5\%)

Table 3 shows the results of the classical assumption test, which show that the significance of all test findings is greater than $5 \%$. As a result, it may be stated that the data utilized in both models pass the classical assumption test. Then, as shown in Tables 3 and 4, the Model 1 and Model 2 regression results can be computed.

Table 4 shows that the regression findings in Models 1 and 2 (Conventional Stock Market (CSPI) and Sharia index (JII)) indicate no difference. The stock market's composite index is unaffected by inflation. On both stock markets, the exchange rate has a favorable impact.
It indicates that if the rupiah exchange rate rises, the asset value of the two stock markets rises as well, resulting in a higher share offering. It is based on the Tobins'q theory [14] and earlier study (King \& Kusairi, 2019), which describes the expectation of asset value on investment [15]. The JCI and JII stock markets, on the other hand, were negatively affected by policy interest rates and crisis conditions. It indicates that if policy interest rates rise and a long-term crisis emerges, the value of assets in the CSPI and JII stock markets will be reduced.

Table 4. Long-run regression test results.

\begin{tabular}{|c|c|c|c|c|}
\hline \multirow{2}{*}{ Variables } & \multicolumn{2}{|c|}{ Model 1 (CSPI) } & \multicolumn{2}{c|}{ Model 2 (JII) } \\
\cline { 2 - 5 } & Coefficient & Prob & Coefficient & Prob \\
\hline C & 3126.218 & $0.0000^{* * *}$ & 998514.7 & $0.0000^{* * *}$ \\
\hline Inf & -20.45521 & 0.5750 & 4566.425 & 0.7635 \\
\hline Er & 0.2883 & $0.0000^{* * *}$ & 107.178 & $0.0000^{* * *}$ \\
\hline BIr & -244.3646 & $0.0000^{* * *}$ & -79961.2 & $0.0008^{* * *}$ \\
\hline D & -0.969 .6137 & $0.0000^{* * *}$ & -336087.5 & $0.0000^{* * *}$ \\
\hline
\end{tabular}

Description: (.) P-Value. Level of significance ***(1\%), **(5\%), *(10\%)

Table 5's regression results show a short-term to long-term equilibrium relationship in both stock market models, as evidenced by the negative and significant ECT value [16]. Long-term regression results for the 
two stock market models partially explain why policy interest rates have a negative effect on the stock market index. This is supported by previous research, which shows that interest rates have a significant negative relationship with stock prices [17], and interest rate growth has a significant negative relationship with stock price growth as well [18]. Crisis conditions have a negative effect on the stock market. $t$ is consistent with previous research by reference [19] which stated that the stock market would suffer as a result of the Covid-19 pandemic. Their findings, however, do not match the results of this regression for the exchange rate, which has a positive impact, and inflation, which has a negative impact.

Table 5. Short-run regression test results.

\begin{tabular}{|c|c|c|c|c|}
\hline \multirow{2}{*}{ Variables } & \multicolumn{2}{|c|}{ Model 1(CSPI) } & \multicolumn{2}{c|}{ Model 2 (JCI) } \\
\cline { 2 - 5 } & Coefficient & Prob & Coefficient & Prob \\
\hline $\mathrm{C}$ & 26.0007 & 0.1092 & 9219.619 & 0.2167 \\
\hline $\mathrm{dInf}$ & -29.2988 & 0.3205 & -1067.14 & 0.4375 \\
\hline $\mathrm{dEr}$ & -0.2530 & $0.0000^{* * *}$ & -86.7332 & $0.0001^{* * *}$ \\
\hline $\mathrm{dBIr}$ & -109.0788 & 0.1607 & -33040.94 & -244.3646 \\
\hline $\mathrm{dD}$ & 237.6544 & 0.1714 & 216970.3 & $0.0075^{* * *}$ \\
\hline $\mathrm{Ect}$ & -0.0911 & 0.0205 & -0.1322 & 0.0025 \\
\hline
\end{tabular}

Description: (.) P-Value. Level of significance ***(1\%), $* *(5 \%),{ }^{*}(10 \%)$

In both markets, the conclusions are nearly identical in the short term, meaning that inflation and policy interest rates have no influence. The exchange rate has a negative impact on the stock market; this finding is consistent with reference [20] and reference [17] research findings. However, there are short-term changes in the findings on the crisis variable. The crisis had little impact on the CSPI stock market. The crisis variable, unlike the JII stock market, has a positive effect. This conclusion is significant because it reveals disparities in the behaviour of investors who believe that, despite the crisis, it is safe to continue investing in the Islamic stock market in the short term.

\section{Conclusion}

The cycle of economic activity is indicated by the conditions of economic fluctuations. As a result, monetary policy is required to overcome unfavourable financial conditions. For the long term, the findings are the same in both stock market models (conventional and Islamic stock markets). For the time period under consideration, it appears that inflation has no effect on the two stock markets. It implies that it has the ability to control the level of economic fluctuations in the event of price increases. The stock market benefits from changes in exchange rates. It demonstrates that the exchange rate is closely related to the value of stock market assets. The stock market suffers as a result of interest rate policies and crisis conditions.

In this case, the Covid-19 pandemic could cause a decline in the stock market's stock price index. Longterm investors prefer not to invest in the event of a crisis. In an increase in interest rates, monetary policy through interest rates can also reduce demand in the stock investment market. In order to maintain price stability, interest rates are raised when inflation occurs.

Another important short-term finding is that exchange rates have a negative impact on the two stock markets. The crisis variable, on the other hand, has a positive impact on the JII stock market. It reinforces the difference in investor behaviour when deciding whether or not to invest in times of crisis in the short term. Investors will choose to invest if they are confident in the safety of their assets. Policy recommendations based on these findings are required in order to develop effective strategies.

\section{References}

1. Rasaki MG, Malikane C. Macroeconomic shocks and fluctuations in African economies. Econ Syst [Internet]. 39(4):675-96 (2015)

2. Suryahadi A, Al Izzati R, Suryadarma D. The Impact of COVID-19 outbreak on poverty: An Estimation for Indonesia (Draft). SMERU Work Pap [Internet] (2020)

3. Altinoglu L. The origins of aggregate fluctuations in a credit network economy. J Monet Econ [Internet] (2020)

4. He Y, Lin B. Time-varying effects of cyclical fluctuations in China' s Energy. Energy (2018)

5. Ramzi K, Asma M, Chebbi A. Growth, fluctuations and macroeconomic policies: Evidence from Arab open economies. Econ Anal Policy [Internet] (2017)

6. Zhang Y. Unemployment fluctuations in a small open-economy model with segmented labour markets: The case of Canada. Q Rev Econ Financ [Internet] (2018)

7. McKibbin WJ, Fernando R. The global macroeconomic impacts of COVID-19: Seven Scenarios. SSRN Electron J (2020)

8. Fernandes N. Economic effects of coronavirus outbreak ( COVID-19) on the world economy Nuno Fernandes Full Professor of Finance IESE Business School Spain. SSRN Electron Journal, ISSN 1556-5068, Elsevier BV,. (2020) 
9. Baker S, Bloom N, Davis S, Terry S. COVIDinduced economic uncertainty. Natl Bur Econ Res, (2020)

10. Baldwin R, Mauro BW di. The Economic Effects of a Pandemic [Internet]. Economics in the Time of COVID-19. CEPR Press; (2020)

11. Gujarati DN. Basic Econometrics. McGrow Hill; (2003)

12. Moosa IA, Vaz JJ. Financial markets, institutions \& money cointegration, error correction, and exchange rate forecasting q. J Int Financ Mark Institutions Money [Internet]. (2016)

13. Granger CWJ. Investigating Causal Relations by Econometric Models and Cross-Spectral Methods. Econometrica (1969)

14. Chappell HW, Cheng DC. Expectations, Tobin's q, and investment: A Note. J Finance (1982)

15. Qing YK, Kusairi S. The Effect of money supply, exchange rate, and interest spread toward the performance of stock market in Malaysia. Widyakala J (2019)

16. Miller SM. Monetary dynamics : An Application of cointegration and error-correction modeling. Journal of Money, Credit and Banking, (1991)

17. Khan MK. Impact of exchange rate on stock returns in Shenzhen Stock Exchange: Analysis through ARDL Approach. Int J Econ Manag (2019)

18. Uddin G, Alam MM. The Impacts of interest rate on stock market: Empirical evidence from Dhaka Stock Exchange. South Asian J Manag Sci Vol 4(1), pp 21-30, (2010)

19. Rahmayani D, Oktavilia S. Does the Covid-19 pandemic affect the stock market in Indonesia? J Ilmu Sos dan Ilmu Polit, (2020)

20. Suriani, Majid MSA, Masbar R, Wahid NA. Macroeconomic determinants of the capital market in Indonesia: A Comparative analysis between sukuk and bonds markets. Int $\mathrm{J}$ Acad Res Econ Manag Sci, (2018) 